\section{Animal experimentation (but without man at the centre of the universe)}

SIR

In a recent issue of this journal, a biomedical researcher tried to justify the use of animals in scientific inquiry (1). On the basis of Thomas Aquinas's philosophy, the author continued to argue very eloquently that man should not feel any remorse about his practice of animal research: as Aquinas has already pointed out, man is the true centre of the universe and man's rights arise from his unique intellectual capacity.

This is an old argument indeed, for man has always exploited animals in the dogmatic belief that the exclusive right to do so is bestowed on him by some higher power. However, evolution theory and neurobiological research have led to the conviction that we share many of our sensory and cognitive skills with our animal relatives (2). Peter Medawar (3) properly observed that not even religious fanatics can be very certain nowadays that animals were only put on this earth to be used and abused by man. Recently, the ethics of human-animal relationship have changed dramatically. Performing animal research without committing oneself has become impossible. Clarity and transparency is expected from animal researchers. And most researchers for their part take the real and difficult dilemmas involved in carrying out animal experiments seriously (4).

Without doubt, Martin's (1) remains a very worthy endeavour. But I do not believe one can justify the use of animals in research by putting man at the centre of the universe. One can not short- circuit the moral obligation of scientists to account to the general public for their interventions. Of course, it could be an act of compliance towards those members of the scientific community, presently in a state of alarm, who face increasingly influential animal rights movements. Research institutes are spied upon and sometimes violently harassed by animal-rights activists. If we believe Colin Blakemore (5), 'medical research is fighting for its survival against an upsurge of animal rights activity'. Professor Martin's article goes along very well with Blakemore's plea to 'resist the philistine forces that would stop the progress of medicine'. Martin tries to settle the matter once and for all. He does not seem to understand why there should be any moral dilemma about animal experimentation at all. Surely, being its centre, man can play God in his own universe.

But Martin is not as tough as he would like us to believe for he does not allow any cruelty to animals. It is as though he feels that this would really be too hard to justify. Nevertheless, it is a strange jump in one's train of thought if one is convinced animals have no interests of their own. He makes an effort to explain this jump by arguing that cruelty to animals is inadmissible because the who is cruel to animals is more likely to be cruel to his fellowman'.

Is Martin implicitly accepting that cruelty to animals is related to cruelty to human beings? Surely, this would mean that the same moral rules hold good universally for humans as well as for animals? This would be defensible since the difference between animals and human beings is neither discrete nor abrupt but rather continuous and gradual. But Martin clearly states that animals have no true rights, they only have them by analogy. Thus his reasoning is a bit contradictory for on the one hand he seems to be accepting that cruelty to animals is in effect related to cruelty to human beings, but on the other hand he does not accept that the same moral rules hold for humans and animals alike.

Moreover, why should it be at all so that being cruel to animals makes one more likely to be cruel to one's fellowman? Are we not able to make the distinction between those life forms which have rights and those which have none? Or is it indeed so difficult to differentiate between the two because in many situations animals and humans react in the same manner and seem to experience the same sensations and perceptions. In fact, much of psychological research has been made possible by virtue of the fact that this difference is quantitative and not qualitative. But even if there should exist such a qualitative difference between man and beast, could we then as scientists take a positive correlation for granted between cruelty to animals and cruelty to humans? I do not think so.

Another point is made by leading animal rights philosopher Peter Singer (6). Singer argues that if we are to make a distinction between life forms on the basis of mental capacity, as Martin does (and Thomas Aquinas for that matter), membership of our species has no moral significance in itself. Nevertheless, mental capacity can be useful in differentiating between the relative value of the life of different beings. 'If we are forced to choose between saving the life of a being who understands the meaning of death and wants to go on living, and a being who is not capable of having desires for the future because the being's mental capacities do not enable it to grasp that it is a self, a mental entity existing over time, then it is entirely justifiable to choose in favour of the being who wants to go on living,' Singer (7) writes. On these grounds I believe that some research on human embryos or even on adults could be justifiable, 
whereas some research on animals could very well be inadmissible.

In the long run, biomedical research aims at the alleviation of human suffering and pain. If he accepts this as his guiding principle, it is the duty of the scientist to arrange even his daily research activities in keeping with this principle. Moreover, scientists have an obligation towards the general public to justify their activities. The once romantic image of an esoteric scientific community of unworldly grey-haired men who do their extremely learned research in dark rooms inaccessible to the uninitiated, is now no longer accepted. The US Public Health Service has understood this and has begun an unprecedented and expensive effort to promote the importance of animal experimentation (8). A spokesman for the service declared they are not intending to ignore the criticism from the animal right movements and that they will explain the use of animals in biomedical research to the public just as they explain everything else they do. Surely these and other initiatives will create a climate of openness and mutual understanding. In such a climate there will be no room for dogmatic arguments that seem not to listen to opposing views, like the one proposed by Martin (1). The feasibility of animal experiments needs to be discussed openly and democratically, but without man at the centre of the universe.

\section{References}

(1) Martin J. The rights of man and animal experimentation. Fournal of medical ethics 1990; 16: 160-161.

(2) Porter D G. Animal experiments. Nature 1989; 340: 180.

(3) Medawar P B. The limits of science. New York: Harper and Row, 1984.

(4) Morton D B. Use of animals in research. Nature 1989; 340: 10.

(5) Blakemore C. Misguided thinking on animals. Nature 1989; 339: 414.

(6) Singer P. Animal experimentation is based on the presupposition that the interests of animals count for little or nothing. Scientific European 1990, suppl to Scientific American 263.

(7) See reference (6): 8-9.

(8) Anderson G C. US takes the offensive on animal research. Nature 1990; 344: 477.

R D'HOOGE, Laboratory of Neurochemistry, Born-Bunge Foundation, University of Antwerp,

Universiteitsplein 1, B-2610 Antwerp, Belgium.

\section{Man is qualitatively different from animals}

SIR

Mr D'Hooge's letter needs reply since he puts words into my mouth that do not follow from what I wrote and since I disagree with his views on animal experimentation. An analysis of his stance shows that the principles on which he bases his attitude to animal experimentation are twofold:

1. Man is part of a biological continuum with the rest of nature, therefore he is part of a moral continuum.

2. Rights should be based upon an individual 'grasping' that it is a self.

I wish to comment on both these propositions:

1. The view that rights should arise from the biological status of an individual is the narrow view of the biologist who does not take account of the totality of man. Man is part of a biological continuum (I stated so in my article) that extends quantitatively from man to amino acids, however man has something that is qualitatively different from the rest of the known universe. This human principle is more valuable than the biological continuum and man's rights arise from it. What is a right? Where does it come from? Aristotle's definition is a right is that which must be given to a man. The right must have a reason that supports it. This reason is pragmatic and is supported by an analysis of the consequences of not having the right. If there is unavoidable competition between man and another species then man must be given certain rights which if he lacked might lead to his downfall. Even though animals are immensely valuable, man is more valuable since he is qualitatively different in a superior way. D'Hooge says that I distinguish between man and animals on 'mental capacity'. If this means ability to reason, to remember and use tools alone that is not so. The difference lies in man's possessing the ability to put two abstract concepts together and produce a third abstract concept which is different from the original two. If an apparatus, of whatever sort, has to be like the thing it manipulates (by definition), then man must have an abstract apparatus. This is valuable because it produces valuable things. Man therefore has to be protected more than any other thing. There is no evidence that animals can put two abstract concepts together and produce a third that is different. However, I am not absolutely certain that this is so. The level of certainty falls within Aristotle's definition of moral certainty, ie one has sufficient level of certainty to take action, but one acknowledges the possibility of the opposite being true. This is the level of certainty that pertains in most philosophical conclusions, but not in biology where the possibility of a conclusion not occurring by chance can be calculated.

The day I read Mr D'Hooge's letter, I attended a performance of Handel's Ricardo Primero, with his thoughts on man and animals in my mind. The opera contained abstraction on abstraction and was watched by human beings taking part in a complex cultural event. It was a story of the most subtle communication

individuals. It concerned of history and geography. An understanding of the opera required an understanding of, on the one hand, the origin of the nation state, on the other, the relationship between physical and spiritual love. It related to concepts of religion and ceremony. All this was presented in language and music. The action potential in the recurrent laryngeal nerve of the singers lay on a continuum of action potentials from man to the squid. Yet that necessary biological function was all but irrelevant to the true value of the human activity on the stage. The individual and collective behaviour I was observing was qualitatively different from any purely biological activity in the world. This is understood by both mediaeval scholastic and Marxist philosophers alike, but not by biologists who see no further than man's physical destiny. Of course the deer running through the greenwood is valuable, but man's behaviour is more valuable. Both should be valued, but if there is competition as in the need for animal experimentation for human medical progress, then man must come first.

Biologists should ask themselves what is the destiny of the world. Is it biological excellence via research or 